\title{
THEORETICAL AND CONCEPTUAL BASIS OF BUDGET SECURITY: REGIONAL AND LOCAL DIMENSION
}

\author{
HALYNA VOZNYAK, TARAS KLOBA
}

\begin{abstract}
In current conditions, budget security is one of the essential components of financial security. The budget is the leading financial plan of the state and reflects most of the economic processes in the country; it also redistributes and accumulates revenues, provides financing of vital costs. Proper use of the budget as a financial basis for state regulation of a market economy should ensure the rule of economic and social processes in the interests of society to create conditions for the economic development of the country. On the one hand, and Budget security reflects the regularities of the functioning of the budget as an objective reality and, on the other hand, the subjective manifestations of human activity that find their expression in fiscal policy.

The article aims to substantiate budget security's theoretical and conceptual basis at the regional and local levels.

The article examines the theoretical essence of budget security at the regional and local levels. First, scientific approaches to the definition of "budget security" are generalized. Second, budget risks are considered, which under the influence of certain factors can be transformed into threats to budget security (discrete control; insolvency of taxpayers; political, military actions; destabilization of the financial sector of the region/communities; imbalance of revenues and expenditures; structure of revenues and expenses; external dependence violation of the stability of payments, debt growth (internal/external), stochastic errors, corrupt growth of the shadow sector, irrational budgeting). Third, the theoretical conceptualization of the concept of "threat", their essence and characteristics are substantiated. Fourth, understanding the nature of the concept of "budget risk" and "threat to budget security" is investigated. Finally, the functions and tasks that the budget security of territories should perform in the conditions of increasing financial and economic instability are considered.

Coverage of the theoretical and conceptual basis of budget security of regions and communities, specification of existing and potential factors and risks of budget security, functions and tasks of budget security will minimize and neutralize various aspects and threats in budget security and increase budget security at regional and local levels and achieve important strategic guidelines.
\end{abstract}

Keywords: Budget security, budget risk, factors of budget security, financial security, national security, economic security.

JEL Classification: H 61, H 72. 


\section{INTRODUCTION}

An essential prerequisite for economic growth, and thus for the development of regions and communities, is the strengthening of budget security and the predictability of its long-term sustainability. Excessive attention to the budget security of areas and neighbourhoods of Ukraine in recent years is in the field of view of domestic scientists and practitioners because the COVID-19 pandemic challenged regions and communities, exacerbated several risks of their sustainable progress. Further development will depend not only on the near future but also on the distant future. Of course, the burden of quarantine restrictions negatively affected and modified the implementation of public policy (including financial and budgetary), negatively affected economic activity in virtually all sectors of the domestic economy, and thus made it impossible to form a sufficient financial basis for government and local self-government and, accordingly, their ability to exercise their powers and implement development strategies.

Under such conditions, systemic or local financial and economic crises actualize both scientific and practical interest in change, followed by identifying possible ways to revitalize the economy of regions and local communities and consolidate positive trends.

Taken together, this requires a unique approach to identifying and countering threats to the budget security of territories.

\section{THEORETICAL BACKGROUND}

Due to its socio-economic significance, the outlined topic focuses on the scientific research of economic and financial science representatives. Thus, the theoretical and conceptual basis of budget security as outlined in the field of study of both domestic and foreign scientists, namely: O. Baranovskyi [2], O. Vyshnevska, M. Yermoshenko, N. Kravchuk, V. Martyniuk, O. Pidkhomnyi, N. Prokopenko [1], A. Sukhorukov, V. Fedosov, O. Khrystenko, S. Yurii. Despite significant developments, theoretical aspects of budget security at the regional or local level have not been adequately presented and need further discussion. Although the concept of "security," at first glance, seems relatively straightforward and easy to define, it has a wide range of meanings. O. Baranovski notes that budget security is a state of ensuring the solvency (level of budget potential) of the state to perform its functions, taking into account the balance of revenues and expenditures of state and local budgets and the feasibility, legality, and efficiency of budget funds at all levels [3].

According to Z. Varnalii and A. Sukhorukova, budget security is the ability of the budget system to ensure the financial independence of the state and its effective use of budget funds in the performance of social protection, public administration and international activities, financing of science, education, culture and security, health, national security, and defense, implementation of investment and environmental policies.

Interesting is the opinion of domestic scientists. A. Amosha, E. Buleev and N. Prokopenko, who define security as a social category, i.e., security in the main spheres of society (political, economic, socio-domestic, socio-cultural, and social -environmental). "In the scientific works of these researchers, security is identified with inviolability, stability. Security is perceived not only as a state of the social system in which it can function properly and most fully meet the needs of society. In this interpretation, security aims to address the following tasks: dangers, threats, and risks, neutralization of actual and potential threats, providing conditions of protection, i.e., offers active orientation of subjects on maintenance of the safety" [1].

\section{Research Objective, Methodology and Data}

The article aims to substantiate budget securities and conceptual basis at the regional and local levels. The object of research in this article is budget security as a prerequisite for implementing effective regional financial and economic policy to achieve critical strategic guidelines. The 
methodological basis of the study is the theoretical foundations of budget security of the state as a vital component of financial and economic security.

\section{RESULTS AND DISCUSSION}

The issue of budget security research, in the vast majority, is the subject of scientific research by researchers at the level of enterprises, households or the state. However, at the regional or local level, scientific research has not become comprehensive and requires additional discussion. In addition, increasing attention to the problems of budget security of regions and territorial communities in Ukraine is due not only to the dynamics of social processes but also to changes in conceptual approaches to the concept of "budget security" and lack of a unified vision of understanding its essence (Tab. 1).

\begin{tabular}{|c|c|}
\hline The meaning of the concept & Author \\
\hline $\begin{array}{l}\text { Budget security - the ability of the state, with the help of the budget, to perform its functions } \\
\text { and tasks, as well as to meet the needs of taxpayers and recipients budget funds, taking into } \\
\text { account individual, corporate and public interests. }\end{array}$ & O. Kolisnyk [9] \\
\hline $\begin{array}{l}\text { Budget security is a state of ensuring the state's solvency, taking into account the balance of } \\
\text { revenues and expenditures of state and local budgets and the efficiency of budget funds. }\end{array}$ & O. Horalko [8] \\
\hline $\begin{array}{l}\text { Budget security - the state of protection of the budget system and all its elements from } \\
\text { internal and external threats, which ensures the ability of the state to finance the } \\
\text { implementation of its functions by national interests. }\end{array}$ & V. Dets [7] \\
\hline $\begin{array}{l}\text { Budget security is a state of ensuring the state's solvency (level of budget potential) of the } \\
\text { state to perform its functions, taking into account the balance of revenues and expenditures } \\
\text { of state and local budgets and the feasibility, legality and efficiency of budget funds at all } \\
\text { levels. }\end{array}$ & O. Baranovskyi [2] \\
\hline $\begin{array}{l}\text { Budget security is the ability of the budget system to ensure the solvency of the state while } \\
\text { balancing revenues and expenditures and the effective use of budget funds in the process of } \\
\text { state regulation of economic development, implementation of social policy, and maintenance } \\
\text { of public administration, national security and defense. }\end{array}$ & V. Ospishchev [13] \\
\hline $\begin{array}{l}\text { Budget security - the state of protection of the budget system, centralized and decentralized } \\
\text { funds of the state and local governments, which allows in any economic development } \\
\text { conditions to adequately respond to internal and external threats while ensuring sustainable } \\
\text { socio-economic development of the state, regions and municipalities. protection of economic } \\
\text { interests of the individual, society and the state. }\end{array}$ & $\begin{array}{l}\text { Maksymov Yu. A. } \\
\text { [12] }\end{array}$ \\
\hline $\begin{array}{l}\text { Budget security is the ability of the budget system to ensure the financial independence of } \\
\text { the state and its effective use of budget funds in performing the functions of social } \\
\text { protection, public administration and international activities. }\end{array}$ & O. Demenok [6] \\
\hline $\begin{array}{l}\text { Budget security - the ability of the budget sys } \\
\text { independence through the rational use of budget fu }\end{array}$ & N. Bohomolova [5] \\
\hline $\begin{array}{l}\text { In a broad sense, it is a state of protection of vital interests of the financial system of the state } \\
\text { and regions from internal and external threats in budgetary and tax activities and related } \\
\text { relations. In a narrow sense, it is the achievement and maintenance of a stable, balanced in } \\
\text { terms of revenues and expenditures, state and consolidated budgets, the ability of the budget } \\
\text { system to meet the needs of financial resources through tax and other revenues to budgets at } \\
\text { various levels. }\end{array}$ & N. Boboshko [4] \\
\hline $\begin{array}{l}\text { Budget security is the ability of public authorities and local governments to provide funding } \\
\text { through the budgets of all levels of the complete set of powers assigned to them to } \\
\text { implement the rights of citizens guaranteed by the Constitution in the long run under the } \\
\text { destabilizing influence of various factors (threats). }\end{array}$ & M. Stavnycha [14] \\
\hline
\end{tabular}

Tab. 1. The essence and differences of the concept of "budget security".

* Source: compiled by the authors on the basis of these sources 
Understanding budget security, on the one hand, as an essential dominant of territorial development, and on the other - as a criterion for the effectiveness of their fiscal policy, we must agree that this concept, "absorbing the characteristics of political and economic directions, has a dual nature: can be considered as a set of organizational and legal relations, and as an indicator of the development of the budget system and the efficiency of the budget process, a criterion for evaluating budget policy [9].

Researching from the standpoint of regional and local dimensions, tend to believe that the essence of budget security is revealed by the ability of government or local government to ensure the stability of the budget system (threats and challenges), the maximum degree of balance of local budgets, neutralize external and internal threats. and the use of budget funds to ensure the sustainable development of territories. In other words, the budgetary security of the regions is manifested in the peculiarities of government and local self-government to ensure the sustainability of economic and social development; neutralize the action of external and internal factors; to prevent financial irregularities at all stages of the budget process, and most importantly - to implement a budget policy that will focus on ensuring the implementation of strategic development goals of a particular region or territorial community, strengthening their competitiveness and investment attractiveness.

The importance of budget security is challenging to overestimate because it depends on it to guarantee resident's constitutional rights, including education, health care, physical security and more. There is also an understanding that strengthening the budgetary security of territories is the key to balanced economic growth, ensuring high living standards and welfare.

The study of problems related to the identification and construction of an effective system for counteracting the negative impact of threats to budget security of regions and communities is closely related to the title of budget risks that under certain factors can be transformed into threats to budget security (Fig. 1).

Thus, the most common risks of budget security that occur at the regional or local level include the risk of discrete control, the essence of which is to differentiate in time the stages of budget planning and implementation, which complicates the rapid determination of the effectiveness of these stages of the budget process. The level of risk is reduced if the maximum possible approach of the planning moment to the reporting moment is reached, for example, a quarterly breakdown of planned budget indicators [11, p. 138-141]; the risk of insolvency of taxpayers to local budgets, which is manifested in the deterioration of the financial condition of registered taxpayers in the region (which in turn may be a consequence of the financial and economic crisis); the risk of mismatch of terms of revenues and expenditures to local budgets, which leads to temporary gaps between the filling of budget funds and their use; income/expense structure risk associated with the dominance of a significant proportion of similar revenues (or priority expenditures); the risk of external dependence is manifested in the low capacity of the territories to generate their incomes.

Theoretical calculations of the essence of budgetary security of territories will not be completed if we do not touch on the theoretical conceptualization of the concept of "threat", the essential characteristics of which reveal the following provisions [11, p. 138-141]:

- destructive, destabilizing nature - one of the main characteristics of the concept: the threat has a negative impact, leads to undesirable changes, disrupts the normal state of the economic system, its stability and development, can lead to its termination;

- dynamism - if we consider the threat not only as a phenomenon but also as a specific process or action of third parties, it becomes evident that its destructive nature can not be static; it is constantly changing either in the direction of increase or in the order of weakening its negative impact, which, determines the different level of security, its presence or absence at specific times;

- uncertainty about the nature of the impact over time - the very concept of "threat" does not reflect whether actual or potential is a particular phenomenon (process, event, etc.), threat - is either the possibility or certainty of this phenomenon (process, event) and therefore to specify the nature and options of influence in time should use the concepts of "real threat" and "potential threat"; 


\section{Factors influencing budget security}

- Pandemic, hostilities, financial and economic instability;

- monetary and non-monetary, inflation;

- predictability of MB revenues and their expenditures;

- degree of MB balance;

- the quality of the regulatory framework and the degree of regulation of the budget process;

- transparency of the budget process, control over the spending of budget funds and compliance with the budget process procedure;

- volumes of state investments;

- tax benefits for economic entities;

- coordination of interests: state-regions-communities-residents.

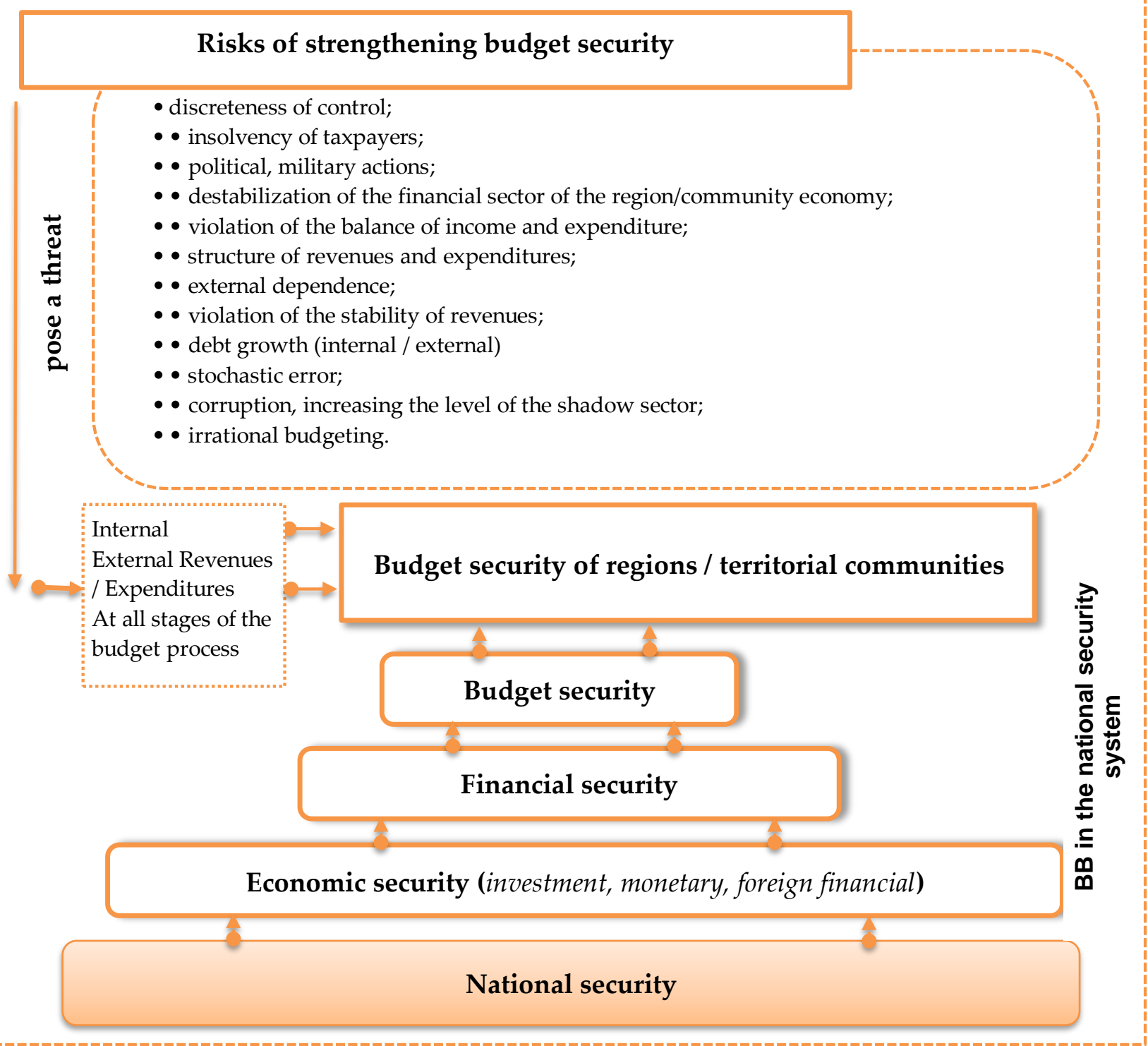

* Source: compiled by the authors

Fig. 1. Budget security of regions and communities: factors and risks.

- potential impact - in the interpretation of the concept of "security" clearly defined nature of destructive impact - potential, i.e. threat - is something that will negatively affect in the future, and therefore even if it is a real threat, it means that there is a particular phenomenon (process, action) that 
will lead to negative consequences in the future; if we are talking about a potential threat, it means that a specific destructive phenomenon may or may not occur; in the event of a threat, it will become real, which in turn will lead to negative consequences.

In the scientific and expert environment, depending on the level of management that will apply countermeasures (or neutralization of threats), it is customary to distinguish between external and internal threats; by the duration of exposure - permanent, long-term, temporary; depending on the ability to predict - predicted, unpredictable and difficult to predict [11, p. 138-141].

In the context of this study, we believe there is a need to detail and generalize approaches to understanding the essence of "budgetary risks" and "threats to budget security". The fact is that in an unstable economy (as we now see), risk assessment and threat assessment is of archival importance in management decisions, whether at the regional or local level (which will be discussed below).

They tend to believe that "risks" and "threats" are not synonymous (although in the scientific literature, such an opinion also exists) because a) risk is the probability of an event that can have both positive and negative impacts on the budget system, while the threat is a clearly defined negative impact on the subject (or a factor that leads to the deformation of the budget system); $b$ ) if the risks can be assessed quantitatively, then the threats - only qualitatively (because you can only assess the losses from the threat to determine the level of danger) by the severity of the consequences; c) in contrast to threats that are uncontrolled by socio-economic systems, risks can be managed.

In conditions of increasing financial and economic instability, it makes sense to talk about the functions and tasks that should be performed by the budgetary security of the territories (Table 2).

\begin{tabular}{|l|l|}
\hline \multicolumn{1}{|c|}{ Functions } & \multicolumn{1}{c|}{ Task } \\
\hline $\begin{array}{l}\text { Preventing the intensification of } \\
\text { crisis phenomena, their } \\
\text { neutralization, and thus } \\
\text { strengthening the controllability of } \\
\text { the socio-economic situation in the } \\
\text { region or territorial community }\end{array}$ & $\begin{array}{l}\text { to monitor budget indicators of formation and implementation of } \\
\text { budget policy of territories; } \\
\text { identify the factors that pose a threat to the budget system of regions, } \\
\text { systematize them and, if possible, assess the strength of the impact; } \\
\text { develop anti-crisis measures to manage risks or minimize threats } \\
\text { (consequences) and clarify the list of strategic and tactical goals of } \\
\text { budget management; }\end{array}$ \\
\hline $\begin{array}{l}\text { Stabilization of the budget system of } \\
\text { territories, forecasting and crisis } \\
\text { prevention }\end{array}$ & $\begin{array}{l}\text { to monitor budget indicators of formation and implementation of } \\
\text { budget policy of territories; } \\
\text { develop measures to strengthen budget security; } \\
\text { to forecast the state of budget security taking into account stabilization } \\
\text { measures; }\end{array}$ \\
\hline $\begin{array}{l}\text { Sustainable development of the } \\
\text { budget system, improvement of the } \\
\text { budget process, immediate } \\
\text { neutralization of risk factors }\end{array}$ & $\begin{array}{l}\text { to monitor budget indicators of formation and implementation of } \\
\text { budget policy of territories; } \\
\text { identify potential threats, assess the strength of the impact and possible } \\
\text { violations of the sustainable state of budget security; } \\
\text { develop measures to develop the budget system and strengthen budget } \\
\text { security in the long run. }\end{array}$ \\
\hline
\end{tabular}

Tab. 2. Functions and tasks of budgetary security of regions and communities.

* Source: compiled by the authors

Based on the study, we can conclude that today the development of budget security of regions and communities plays an important role. In addition, the priority role of budget security in the financial security of the state is determined by the objective necessity of the budget, its purpose of ensuring the state's functions financially and implementation of its economic strategy, redistribute part of gross domestic product, regulate economic and social processes in the state economic sovereignty and stability. Therefore, ensuring budget security is among the critical tasks of the state in implementing its strategic socio-economic priorities. 


\section{CONCLUSIONS}

Summarizing the theoretical foundations of budget security of territories, we add that determine its (budget security) set of conditions under which the protection of financial and economic interests of parts and the maintenance of budget parameters within the norms. Due to this, the economy of regions and communities retains the ability to meet the needs of residents, generate innovative changes and competitive advantages.

The study makes it possible to outline the primary theoretical and conceptual basis of budget security in the region. Accordingly, the formation of economic security of the area should take place: a) comprehensively and taking into account all aspects of a regional policy; b) systematically, taking into account all relationships; c) variably, i.e., with the justification of some options for neutralization or elimination of threats, with the definition of potential risk.

Thus, the excessive relevance and logical incompleteness of research in the outlined plane require further scientific research, which will provide a deeper understanding of the problems of strengthening budget security, taking into account the strategic directions of the development of territories.

Acknowledgements. The research was performed within the project "Financial determinants of economic growth of regions and territorial communities based on the behavioural economy" (registration number 2020.02 / 0215), supported by NFDU (Competition "Support to the research of leading and young scientists").

\section{REFERENCES}

[1] Amosha A.I., Buleev, E.T. and Prokopenko N.D. Theoretical and applied aspects of the functioning of the industrial complex of the region. Donetsk: NAS of Ukraine; Institute of Industrial Economics; Institute for Economic and Legal Research, 2004. (in Ukrainian)

[2] Baranovskyi O.I. Financial security. Kyiv: National Academy of Sciences of Ukraine, Institute of Economic Forecasting, 1999. (in Ukrainian)

[3] Baranovskyi O.I. The essence and factors of budget security. Economy and region, 2 (2016), 20-29.

[4] Boboshko N.M. The relevance of ensuring the economic security of the budgetary system of the state. Innovative development of the economy, 1 (31) (2016), 223-226.

[5] Bohomolova N.I. The effectiveness of budget policy in the system of financial security of the state. Efficient economy, (11) (2011), Available at: http://www.economy.nayka.com.ua/?op=1\&z=759.

[6] Demenok O.V., Hlukhova V.I. Budget security of Ukraine as a component of financial security of the state: state and prospects. Science and economics. Financial system, 1 (17) (2010), 18-23.

[7] Dets V.F. Interbudgetary regulation in the system of economic security of the state: Extended abstract of candidate's thesis. Kyiv: National Institute of International Security Issues, 2008. (in Ukrainian)

[8] Horalko O.V. Budget component of the financial security system. Scientific Bulletin of NLTU of Ukraine, 23.1 (2013), 230-237. (in Ukrainian)

[9] Kolisnyk O. Asymmetry of territorial development and interbudgetary relations: impact on the state of budget security of Ukraine. The world of finance, 3 (16) (2008), 64-72. (in Ukrainian)

[10] Kolisnyk O. Ya. Budget security in ensuring the strategy of socio-economic development of the state: Extended abstract of candidate's thesis. Ternopil: Ternopil National Economic University, 2009. (in Ukrainian)

[11] Koval L.P. Axiomatics of the study of threats to the budget security of the region as a component of its financial security. Scientific Bulletin of Kherson State University, 9-1 (2014), 138-141.

[12] Maksymov $\mathrm{Yu}$. A. Ensuring the economic (financial and budgetary) security of the Russian Federation in the field of state regulation of foreign trade activities: Extended abstract of candidate's thesis. St. Petersburg: Saint Petersburg State University of Economics, 2015. (in Russia)

[13] Ospishchev V.I., Lachkova, L.I. \& Blyzniuk, O.P. Finances. Kyiv: Knowledge, 2008. (in Ukrainian) 
[14] Stavnycha M.M. Budget security of the region in the context of effective socio-economic development. Collection of scientific works of the National University of the State Tax Service of Ukraine, 1 (2012), 386-394.

Address: Halyna Voznyak, Taras Kloba, SI “Institute of Regional Research named after M. I. Dolishniy of the NAS of Ukraine", 4, Kozelnytska Str., Lviv, 79026 Ukraine.

E-mail: gvoznyak@gmail.com, taras.kloba@gmail.com.

Received: August 19, 2021; revised: September 26, 2021.

Возняк Галина, Кльоба Тарас. Теоретико-концептуальний базис бюджетної безпеки: регіональний і локальний вимір. Журнал Прикарпатського університету імені Василя Стефаника, 8 (3) (2021), 60-67.

В сучасних умовах бюджетна безпека є однією з важдивих складових фінансової безпеки, оскільки бюджет є основним фінансовим планом держави і відображає більшість фінансових процесів в країні, також він перерозподіляе та акумудює доходи, забезпечує фінансування життєво необхідних витрат. Правильне використання бюджету як фінансової бази державного регудювання ринкової економіки повинно забезпечувати регулювання економічних і соціальних процесів в інтересах суспільства, створювати передумови ддя економічного розвитку країни. Бюджетна безпека відображає з одного боку закономірності функціонування бюджету як об’єктивної реальності, а 3 іншого суб'єктивні прояви дюдської діяльності що знаходять свій вираз у бюджетній політиці.

Метою статті є обгрунтування теоретико-концептуального базису бюджетної безпеки на регіональному та місцевому рівнях.

У статті досліджено теоретичну сутність бюджетної безпеки на регіональному та місцевому рівнях. Узагальнено наукові підходи до визначення поняття "бюджетна безпека". Розглянуто бюджетні ризики, які під дією певних чинників можуть трансформуватись в загрози бюджетній безпеці (дискретність контролю; неплатоспроможність платників податків; політичні, воєнні дії; дестабілізація фінансового сектору економіки регіону /громад; порушення балансу доходів і видатків; структура доходів і видатків; зовнішня залежність; порушення стабільності надходжень; зростання боргу (внутрішнього/зовнішнього); стохастичні помилки; корупційне зростання рівня тіньового сектору; нераціональне формування бюджету). Обгрунтовано теоретична концептуалізація поняття "загрози", ї сутність та характеристики. Досліджено розуміння сутності поняття "бюджетний ризик" i "загроза бюджетній безпеці". Розглянуто функції та завдання, які повинна виконувати бюджетна безпека територій в умовах посилення фінансово-економічної нестабільності.

Висвітлення теоретико-концептуального базису бюджетної безпеки регіонів i громад, конкретизація наявних і потенційних чинників та ризиків бюджетній безпеці, функцій та завдань бюджетної безпеки дасть можливість мінімізації та нейтралізації різних чинників та ризиків в бюджетній безпеці, і дозволить підвищити рівень бюджетної безпеки на регіональному та місцевому рівнях та досягти важдивих стратегічних орієнтирів.

Ключові слова: бюджетна безпека, бюджетний ризик, чинники бюджетної безпеки, фінансова безпека, національна безпека, економічна безпека. 